\section{Global Proceedings Repository \\ American Research Foundation}

ISSN 2476-017X

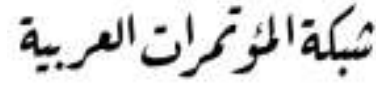

http://arab.kmshare.net/

Available online at http://proceedings.sriweb.org

The Ninth International Scientific Academic Conference

Under the Title "Contemporary trends in social, human, and natural sciences"

$$
\text { المؤتمر العلمي الاكاديمي الدولي التاسع }
$$

تحت عنوان "الاتحاهات المعاصرة في العلوم الاجتماعية، الانسانية، والطبيعية"

17 - 18 يوليو - تموز 2018 - اسطنبول - تركيا

http://kmshare.net/isac2018/

\title{
Linguistics at the Service of Machine Translation: Modality as an
}

\section{Example}

\section{Sarah Eid}

Al Maaref University, Beirut, Lebanon

July 2018

\begin{abstract}
Disagreement between linguists and translation theorists has been incessant as linguists consider linguistics as an essential part in the translation process while translation theorists consider translation as a discipline that stands by itself with its own strategies and theories. However, though this dispute isn't recent, no one has tried to show how linguistic topics can serve in the understanding of a sentence and how should the tagging process be for Machine Translation (MT). This paper highlights the long clash between linguists and translation theorists, the history of machine Translation, the definition of modality, the types of modality, the factors that affect the meaning of a certain modal in a sentence, and the tagging of modals to best use them in machine translation. It also attempts
\end{abstract}




\section{Global Proceedings Repository \\ American Research Foundation}

ISSN 2476-017X

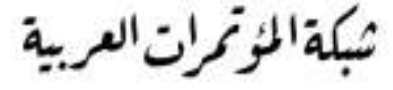

http://arab.kmshare.net/

Available online at http://proceedings.sriweb.org

The Ninth International Scientific Academic Conference

Under the Title "Contemporary trends in social, human, and natural sciences"

$$
\text { المؤتمر العلمي الاكاديمي الدولي التاسع }
$$

تحت عنوان "الاتحاهات المعاصرة في العلوم الاجتماعية، الانسانية، والطبيعية"

$$
17 \text { - } 18 \text { يوليو - تموز } 2018 \text { - اسطنبول - تركيا }
$$

http://kmshare.net/isac2018/

to show how linguistics is at the service of MT if it is well exploited according to the linguistic epistemic tagging mainly the tagging of modals and the adjacent parts of speech in order to give correct translation when using MT. Qualitative research is conducted through comparing a set of bilingual English-Arabic samples from the UNDP documents in order to come up with rules that fortify the abovementioned assumption. As a conclusion, the researcher shows that modalized translation doesn't work with modals because Arabic doesn't have a defined modal system and the meaning varies from one sentence to another based upon the speaker or writer's opinion or attitude unless taking into consideration the surrounding factors of modals. The comparative analysis will be adopted to show the way the parts of a language function when expressing ideas in other languages (Moindjie, 2015).

Keywords: Machine Translation, Modals, Tagging, Epistemic.

\section{Literature Review}

\section{Linguists vs. Translation Theorists}

The relationship between linguistics and translation theories remained uncertain and tension didn't stop but remained where the German theorist Jorn Albrecht expressed, eight years after the declarations of Chomsky and Catford, his regret and astonishment that linguists hadn't studied translation. Moreover, the linguist Aleksander 


\section{Global Proceedings Repository \\ American Research Foundation}

ISSN 2476-017X

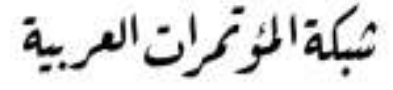

http://arab.kmshare.net/

Available online at http://proceedings.sriweb.org

The Ninth International Scientific Academic Conference

Under the Title "Contemporary trends in social, human, and natural sciences"

$$
\text { المؤتمر العلمي الاكاديمي الدولي التاسع }
$$

تحت عنوان "الاتحاهات المعاصرة في العلوم الاجتماعية، الانسانية، والطبيعية"

$$
17 \text { - } 18 \text { يوليو - تموز } 2018 \text { - اسطنبول - تركيا }
$$

http://kmshare.net/isac2018/

Shveister said that many linguists decided that translation could be the object of linguistic study. Maurice Pergnier, in turn, said that linguistics improved in ways that made it more relevant to the concerns of translation. The Canadian translation theorist Jean Delisle said that the langue-oriented approach that produces useful comparative descriptions of language systems should be part of the knowledge of each translator where he said that he couldn't imagine a translator without the basic knowledge of the languages they master (Fawcett, 2003).

On the other hand, thirty years after Catford and chomsky's declarations, Roger Bell said that translation theorists and linguists had their own separate ways, and Marianne Lederer was one of those who dismissed linguistics from the translation studies where she said that she hoped to bring out the reasons why translation must be dealt with on a different level with linguistics (Fawcett, 2003).

In this study, we will show that linguists have a lot to give to translation and the tagging phase of Machine Translation through applying the findings of linguistics on translation.

\section{Definition of Machine Translation}

According to Trujillo (1999), MT is the application of computational techniques to aid in the translation of texts. MT can master the "mapping" of the grammatical structures of the source and target languages. This is easy 


\section{Global Proceedings Repository \\ American Research Foundation}

ISSN 2476-017X

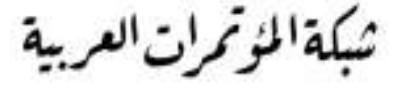

http://arab.kmshare.net/

Available online at http://proceedings.sriweb.org

The Ninth International Scientific Academic Conference

Under the Title "Contemporary trends in social, human, and natural sciences"

$$
\text { المؤتمر العلمي الاكاديمي الدولي التاسع }
$$

تحت عنوان "الاتحاهات المعاصرة في العلوم الاجتماعية، الانسانية، والطبيعية"

17 - 18 يوليو - تموز 2018 - اسطنبول - تركيا

http://kmshare.net/isac2018/

for MT systems, especially when the grammatical structures of both languages are similar. In case of different structures, the target sentence and word order should be restructured to guarantee the correct meaning.

\section{History of Machine Translation}

The origins of machine translation (MT) may be traced back to the seventeenth century but the twentieth century has witnessed the first practical suggestions as two patents were issued in 1933 by the French Georges Artsrouni and Russian Petr Trojanskij. (Hutchins, 2001; Melby \& Warner, 1995).

However, the next MT development attempt was made in March 1947 by Andrew Booth and Warren Weaver who haven't had any knowledge about these precursors when they met in March 1947 and put forward the first tentative ideas for using the newly invented computers for translating natural languages (Hutchins, 2001).

The history of Machine Translation has been affected by the politics, science and economics (Trujillo, 1999). This issue is well shown in the successful employment of computers for deciphering encryption methods during the Second World War (Trujillo, 1999; Melby \& Warner, 1995). 


\section{Global Proceedings Repository \\ American Research Foundation}

ISSN 2476-017X

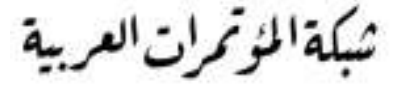

http://arab.kmshare.net/

Available online at http://proceedings.sriweb.org

The Ninth International Scientific Academic Conference

Under the Title "Contemporary trends in social, human, and natural sciences"

$$
\text { المؤتمر العلمي الاكاديمي الدولي التاسع }
$$

تحت عنوان "الاتحاهات المعاصرة في العلوم الاجتماعية، الانسانية، والطبيعية"

17 - 18 يوليو - تموز 2018 - اسطنبول - تركيا

http://kmshare.net/isac2018/

In May 1951, Bar-Hillel was appointed to carry out research at the Massachusetts Institute of Technology (MIT) where he convened, in June 1952, the first MT conference at MIT in collaboration with International Business Machines Corporation (IBM) (Hardmeier, 2014).

On the other hand, a memo by Warren Weaver to put specific strategies for using computers to translate natural languages initiated MT research in the USA and in the rest of the world, with the first public demonstration of a Russian-English prototype MT system in 1954 (Trujillo, 1999). This event led to similar work in the then USSR and other places around the world.

However, enthusiasm faded after the publication of "Bar-Hillel Report" and "the ALPAC Report" which stated that the expectations of MT goals are excessive and unrealistic compared to the poor actual progress (Khalilov, 2009).

Accordingly, research in the field of MT was restricted from the 1950s to the early 1980s (Khalilov, 2009) despite the usage of Systran by many intergovernmental institutions like NATO, the International Atomic Energy Authority, and many companies like General Motors of Canada, Dornier, and Aerospatiale. 


\section{Global Proceedings Repository \\ American Research Foundation}

ISSN 2476-017X

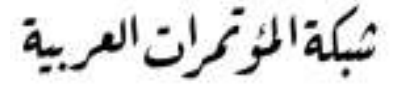

http://arab.kmshare.net/

Available online at http://proceedings.sriweb.org

The Ninth International Scientific Academic Conference

Under the Title "Contemporary trends in social, human, and natural sciences"

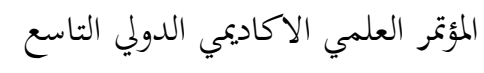

تحت عنوان "الاتحاهات المعاصرة في العلوم الاجتماعية، الانسانية، والطبيعية"

$$
17 \text { - } 18 \text { يوليو - تموز } 2018 \text { - اسطنبول - تركيا }
$$

http://kmshare.net/isac2018/

After a period of recession, the early 1980s witnessed an increase interest in MT such as "Logos" and "Metal" (Khalilov, 2009) in addition to some commercial systems that began to appear (Trujillo, 1999).

From the mid-1980s, less expensive MT systems began to appear as a result of microcomputers prices reduction, the wide availability of text processing tools and a resurrected interest in MT technology from commercial organizations. Nearly all MT research activities at time focused on finding methods for linguistic analysis aimed at expanding an MT system based on traditional rule-based transfer and interlingua approaches. (Khalilov, 2009).

In 1985, another MT system came up from the research conducted at the University of Texas, namely METAL (Mechanical Translation and Analysis of Languages). After METAL attempted Interlingua experiments, it essentially adopted a transfer approach (Khalilov, 2009).

MT bounced back in the 1990s when the first Statistical Machine Translation (SMT) systems were developed due to the result of progress made in computer technology and software engineering in the previous few years (Khalilov, 2009) and a number of companies, particularly Japanese electronics manufacturers, began 


\section{Global Proceedings Repository \\ American Research Foundation}

ISSN 2476-017X

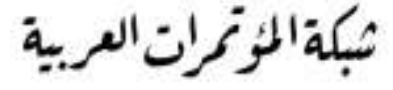

http://arab.kmshare.net/

Available online at http://proceedings.sriweb.org

The Ninth International Scientific Academic Conference

Under the Title "Contemporary trends in social, human, and natural sciences"

$$
\text { المؤتمر العلمي الاكاديمي الدولي التاسع }
$$

تحت عنوان "الاتحاهات المعاصرة في العلوم الاجتماعية، الانسانية، والطبيعية"

$$
17 \text { - } 18 \text { يوليو - تموز } 2018 \text { - اسطنبول - تركيا }
$$

http://kmshare.net/isac2018/

to market MT software for workstations until reaching by the late of 1990s an increased interest in Example-Based MT (Trujillo, 1999).

In the 2000s, the NIST Open Machine Translation (MT) evaluation series commenced in USA; and the Google research team has developed Google-Translate, which operates as free online service for many language pairs including Arabic. In parallel, many MT projects have been initiated in Europe like EuroMatrix and METIS-II, according to the Technische Universitat Dresden.

Nowadays, the statistical approach limited to bilingual lexical examples extracted from parallel training data regardless the existence of many purely statistical and hybrid translation systems with greater powers of generalization the general trend in MT drives toward the generalization of morphologic, syntactic and semantic abstractions that operate within a statistical translation system and complement fundamental models (Khalilov, 2009).

\section{Strategies for Machine Translation}

When talking about MT, researchers deal with the hereunder strategies but no one has, to my knowledge, discussed the tagging that is one of the phases in the automated translation process. 


\section{Global Proceedings Repository \\ American Research Foundation}

ISSN 2476-017X

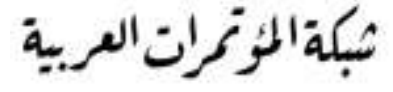

http://arab.kmshare.net/

Available online at http://proceedings.sriweb.org

The Ninth International Scientific Academic Conference

Under the Title "Contemporary trends in social, human, and natural sciences"

$$
\text { المؤتمر العلمي الاكاديمي الدولي التاسع }
$$

تحت عنوان "الاتحاهات المعاصرة في العلوم الاجتماعية، الانسانية، والطبيعية"

$$
17 \text { - } 18 \text { يوليو - تموز } 2018 \text { - اسطنبول - تركيا }
$$

http://kmshare.net/isac2018/

Direct: Direct systems require string pattern matching, with some rearrangement in the Target Language word order without performing any linguistic analysis at all (Khalilov, 2009). This strategy was widely used in early systems and personal computers employ (Trujillo, 1999).

Transfer systems: Transfer systems include the analysis of the source input into a transfer structure that doesn't consider the grammatical details of the Source Language. After analysis, the Source Language is transferred into a corresponding Target Language structure which is later on used to generate a Target Language sentence (Trujillo, 1999).

Interlingua: The Interlingua approach passes through two stages: first, the source language sentence is analyzed into an Interlingua representation i.e. translation is considered a mapping between the semantic spaces of a particular word in the source and target languages (Khalilov, 2009); then, the target text converts the meaning of that representation into an output sentence (Alqudsi, Omar \& Shaker, 2012).

\section{Arabic Machine Translation}




\section{Global Proceedings Repository \\ American Research Foundation \\ ISSN 2476-017X}

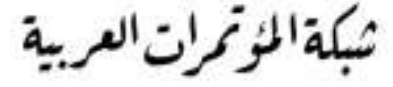

http://arab.kmshare.net/

Available online at http://proceedings.sriweb.org

The Ninth International Scientific Academic Conference

Under the Title "Contemporary trends in social, human, and natural sciences"

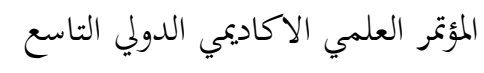

تحت عنوان "الاتحاهات المعاصرة في العلوم الاجتماعية، الانسانية، والطبيعية"

$$
17 \text { - } 18 \text { يوليو - تموز } 2018 \text { - اسطنبول - تركيا }
$$

http://kmshare.net/isac2018/

Although Arabic is one of the major languages on which experimentation in MT was made in the early days of MT and specifically in the US, the first English to Arabic machine translation system was released in the early eighties (Farghali, 2010).

Apart individual work like the Machine Translation designed by Nazlia Omar and "Sakr Software" company - a branch of al-Alamiah Group, there has been no serious work on the development of software packages of machine translation or other applications of natural language processing for Arabic (Zughoul \&Abu Al-Shaar, 2005).

Other Arabic Machine Translation like Systran, Google, Al-mutarjim Al-arabey aren’t designed by Arab companies but by western countries due to the importance of Arabic to globalization, developments in information technology, commerce, and business (Zughoul \&Abu Al-Shaar, 2005).

\section{Approaches for Arabic Machine Translation}

Arabic has peculiarities: it is rich with suffixes and prefixes; Its inflectional and derivational productions introduce a big growth in the number of possible word forms. In this language, articles, prepositions, pronouns, etc. can be affixed to adjectives, nouns, verbs and particles to which they are related. Moreover, Arabic has a relatively free word order, this poses another significant challenge to MT due to the vast possibilities to express the same 


\section{Global Proceedings Repository \\ American Research Foundation}

ISSN 2476-017X

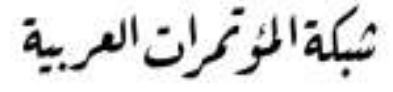

http://arab.kmshare.net/

Available online at http://proceedings.sriweb.org

The Ninth International Scientific Academic Conference

Under the Title "Contemporary trends in social, human, and natural sciences"

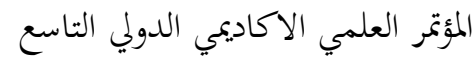

تحت عنوان "الاتحاهات المعاصرة في العلوم الاجتماعية، الانسانية، والطبيعية"

17 - 18 يوليو - تموز 2018 - اسطنبول - تركيا

http://kmshare.net/isac2018/

sentence in Arabic. Therefore, Morphological and syntactic preprocessing is important in order to converge from and into Arabic (Zughoul \&Abu Al-Shaar, 2005).

Guidere mentions two approaches for AMT: The first approach is the "particularistic" which delineate the linguistic idiosyncrasies of Arabic and use them for a local processing approach specific to the internal linguistic system of Arabic. The other approach which is regarded as complementary to the "particularist" approach is called the "universalist", an approach already followed by most of the companies producing software application for Arabic, which explores possibilities of applications of methods already tested on other languages without adaptation.

The abovementioned parts show that researchers have elaborated on the approaches of MT and Arabic Machine Translation without mentioning the tagging process. This issue might be as a result of the clash between linguists and translation theorists.

\section{Tagging}

Tags are the arbitrary words uploaded by users to retrieve specific resources (Dellschaft, 2008). Tags that are used for retrieving specific resources from the system (Dellschaft, 2008) play a basic role in the automated 


\section{Global Proceedings Repository \\ American Research Foundation \\ ISSN 2476-017X}

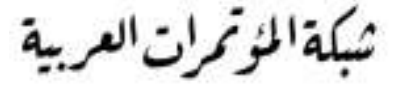

http://arab.kmshare.net/

Available online at http://proceedings.sriweb.org

The Ninth International Scientific Academic Conference

Under the Title "Contemporary trends in social, human, and natural sciences"

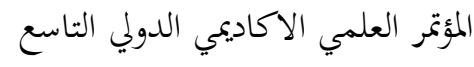

تحت عنوان "الابحاهات المعاصرة في العلوم الاجتماعية، الانسانية، والطبيعية"

17 - 18 يوليو - تموز 2018 - اسطنبول - تركيا

http://kmshare.net/isac2018/

translation because the errors in the tagged corpora hamper the research progress, and tagged corpora include errors which impede the progress of research (Murata, Utiyama, Uchimoto, Ma, and Isahara, 2001)

To my knowledge, the parts of speech tagging adopted nowadays for all MT is not carried by translators that's why the tagging focuses on the grammatical category without taking into consideration the factors that are of necessity for translation because the difficult problems that are faced are the tense, aspect, and modality in Machine Translation (Murata et al., 2001); in other words, the word shouldn't be tagged without knowing the elements that surround it.

The failure of the heuristic rules used for tagging led to the application of the corpus-based approach such as the example-base method, which is the method used in this paper because the POS meaning differs from sentence to another; for example, the word book can be considered a noun or a verb and we need to study the adjacent elements in order to get the suitable tagging.

To conclude, in a sentence, many factors must be taken into consideration before launching the tagging process like the tense, mood, and aspect because when tagging a sentence, we don't tag each POS alone without taking the surrounding elements; for example, if it is a noun phrase, verb ellipsis, interjection or greeting sentences are taken as 


\section{Global Proceedings Repository \\ American Research Foundation}

ISSN 2476-017X

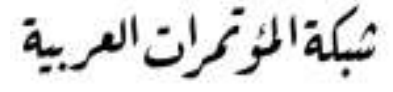

http://arab.kmshare.net/

Available online at http://proceedings.sriweb.org

The Ninth International Scientific Academic Conference

Under the Title "Contemporary trends in social, human, and natural sciences"

$$
\text { المؤتمر العلمي الاكاديمي الدولي التاسع }
$$

تحت عنوان "الاتحاهات المعاصرة في العلوم الاجتماعية، الانسانية، والطبيعية"

$$
17 \text { - } 18 \text { يوليو - تموز } 2018 \text { - اسطنبول - تركيا }
$$

http://kmshare.net/isac2018/

one POS. We take all these factors into consideration because if the correct category is estimated, it should be translated into another language. Therefore, the tagging is manual as it must be though being time consuming. (Murata et al., 2001)

\section{Definition of Modality}

Modality is a semantic grammatical stylistic aspect used to achieve the purpose of an utterance (Moindjie, 2015). According to Halliday, modality is an expression given to a type of meaning that reflects the speaker's intention, judgment or perspective. Palmer (1990) likewise defines modality as the way to convey the speaker's opinions and attitudes. Palmer adds that modality is a cross-language grammatical category that is subject to typological study (Abdel Fattah, 2005).

Vinay and Darbelnet say that modality role is to reflect the speaker's stance according to whether it is considered a fact, a belief, a necessity, etc... they add that every language has its expressive ways in using this aspect. For Carter, Goddard, Reah, Sanger, and Bowring modality deals with the "relationship between the writer and reader of the text (Moindjie, 2015). 


\section{Global Proceedings Repository \\ American Research Foundation}

ISSN 2476-017X

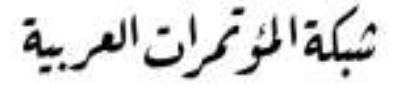

http://arab.kmshare.net/

Available online at http://proceedings.sriweb.org

The Ninth International Scientific Academic Conference

Under the Title "Contemporary trends in social, human, and natural sciences"

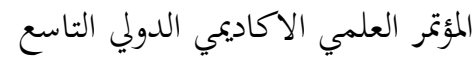

تحت عنوان "الاتحاهات المعاصرة في العلوم الاجتماعية، الانسانية، والطبيعية"

17 - 18 يوليو - تموز 2018 - اسطنبول - تركيا

http://kmshare.net/isac2018/

The concept of modality is vague and not common in all languages to the extent that it may vary within the given language as there might be uncertainties according to the approach: syntactic, pragmatic, semantic, etc... For instance, modality is the modal auxiliary in English while it is composed of the verbs, particles and prepositions in English (Abdel Fattah, 2005). Accordingly, it is not easy to determine the meaning of modality relying on a single perspective. In other words, the elements surrounding the modal should be examined in order to get the correct translation of the modal.

\section{Types of Modality}

Palmer (2001) classifies modality into two categories:

1. Typological modality, directives or Event Modality that are permissive, commissive, and obligative that are the most common type like may, can, and must , have to, and the past tense forms: ought to, should, might, and could (Abdel Fattah, 2005; Moindjie, 2015) and can be of two subcategories: deontic (refers to actions that haven't taken place yet but can take place in the future) and dynamic; and

2. Propositional Modality that can be of two subcategories: epistemic and evidential Abdel Fattah, 2005).

The definition and types of modality are given to justify the process of tagging in the methodology. 


\section{Global Proceedings Repository \\ American Research Foundation}

ISSN 2476-017X

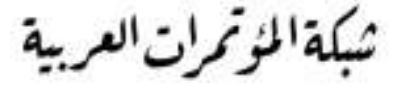

http://arab.kmshare.net/

Available online at http://proceedings.sriweb.org

The Ninth International Scientific Academic Conference

Under the Title "Contemporary trends in social, human, and natural sciences"

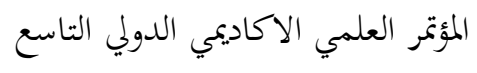

تحت عنوان "الاتحاهات المعاصرة في العلوم الاجتماعية، الانسانية، والطبيعية"

$$
17 \text { - } 18 \text { يوليو - تموز } 2018 \text { - اسطنبول - تركيا }
$$

http://kmshare.net/isac2018/

\section{Methodology}

This research is exploratory in nature based on qualitative method that provides the reader with rich and detailed results and offers ideas and concepts (Centre for Local Economic Strategies [CLES]). Primary and secondary data are required in the current research. Secondary data has been used in the literature review to provide the theoretical and historical grounding concerning Machine Translation. Primary data is collected directly from random economic and educational documents from UNDP. Modals are selected from these documents and then classified according to their categories, subcategories and epistemic tagging of the surrounding elements. These documents were used as the instrument of research through comparing the English and Arabic versions.

The researcher believes that modals can have accurate automated translation if their tagging is based on grammatical syntactic rules and regulations.

\section{Data Analysis}

Translation of modals is a process that should be approached with fine discrimination due do the delicacy of meaning they convey (Abdel Fattah, 2005). There are many factors that affect the translation of the modal: its 


\section{Global Proceedings Repository \\ American Research Foundation \\ ISSN 2476-017X}

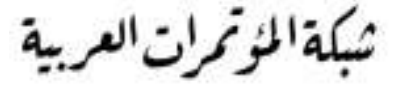

http://arab.kmshare.net/

Available online at http://proceedings.sriweb.org

The Ninth International Scientific Academic Conference

Under the Title "Contemporary trends in social, human, and natural sciences"

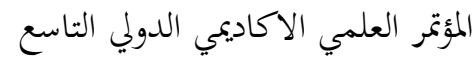

تحت عنوان "الاتحاهات المعاصرة في العلوم الاجتماعية، الانسانية، والطبيعية"

17 - 18 يوليو - تموز 2018 - اسطنبول - تركيا

http://kmshare.net/isac2018/

category, subcategory, surrounding elements i.e. verb, subject, preposition, object, etc..., and semantic indeterminacy i.e. ambiguity (where more than one interpretation is possible) (Murata et al., 2001). Accordingly, translation of modals requires decontextualisation, a textual re-organization, and an accounting for intertextual coherence together with its cultural aspects. The traditional usually known dichotomy between source language and target language orientation does not apply to modal translation (See Table 1) because the general meaning expressed by modals is governed by cognitive processes controlled by: Text-type conventions, Text dynamics (information in the text and audience prior knowledge), and Interpersonal factor (relationship between the writer and the reader) (Abdel Fattah, 2005)

The failure of modals translation is due to the pure linguistic meaning of an utterance with no reference to the context. To best know the meaning of a modal, the tense, aspect intentionality and other extralinguistic factors should be studied to decrease the degree of indeterminacy (Abdel Fattah, 2005)

If the following example is used "You must leave now", it reflects an obligation if the speaker is in higher position; let's suppose an employee in the office of the boss and tells him that the company should deliver an order within 10 minutes, so the usage of "must" shows an obligation; therefore, we should use in Arabic a word that 


\section{Global Proceedings Repository \\ American Research Foundation \\ ISSN 2476-017X}

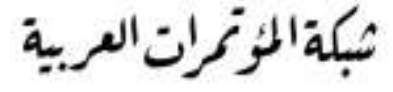

http://arab.kmshare.net/

Available online at http://proceedings.sriweb.org

The Ninth International Scientific Academic Conference

Under the Title "Contemporary trends in social, human, and natural sciences"

$$
\text { المؤتمر العلمي الاكاديمي الدولي التاسع }
$$

تحت عنوان "الاتحاهات المعاصرة في العلوم الاجتماعية، الانسانية، والطبيعية"

$$
17 \text { - } 18 \text { يوليو - تموز } 2018 \text { - اسطنبول - تركيا }
$$

http://kmshare.net/isac2018/

shows an obligation but in a respectful way in order not to embarrass the employee like "ينعيّن عليك الذهاب الآن". However, It is considered an advice if the speaker is in the same position; for example, if it is 8:00 o'clock and friend $\mathrm{A}$ is telling friend $\mathrm{B}$ that the train leaves in 10 minutes and is asking whether he can reach the station; so the reply should be "you must leave now" as it is implicitly an advice that friend A should leave now if they intend arriving on time and not to miss the train; therefore, any word can be used in Arabic like "عليب أن " or "عليك الذهاب تذهب" because there are no formalities.

As noticed from the abovementioned example, there might be several interpretations for the one sentence that might affect its translation but one answer is found when using MT because it occurs without any human interference, so the analysis of the surrounding factors should be taken into consideration (Abdel Fattah, 2005). In addition to the semantic approach, the modal is also affected by the syntactic elements because the translation, for example, changes with the change of the subject pronoun (Abdel Fattah, 2005).

As a conclusion, the linguistic and extralinguistic factors like pragmatics, semantics, grammar, and stylistics influence the process of translation of modals that have subtle social and cultural connotations that the translator doesn't know (Abdel Fattah, 2005). 


\section{Global Proceedings Repository \\ American Research Foundation}

ISSN 2476-017X

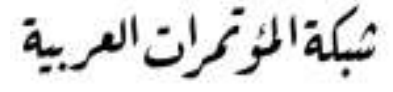

http://arab.kmshare.net/

Available online at http://proceedings.sriweb.org

The Ninth International Scientific Academic Conference

Under the Title "Contemporary trends in social, human, and natural sciences"

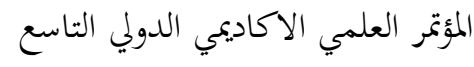

تحت عنوان "الاتحاهات المعاصرة في العلوم الاجتماعية، الانسانية، والطبيعية"

17 - 18 يوليو - تموز 2018 - اسطنبول - تركيا

http://kmshare.net/isac2018/

\section{Tagging of Modality}

The tagging should vary from language to another because every language has its peculiarities. For instance, the semantic-grammatical analysis of modals has been the most successful way for English while it should be inherently different in Arabic; it should be epistemic as will be shown later on. So, trying to translate modals from a SL to a TL without considering all the factors that render perfect is useless and inadequate (Abdel Fattah, 2005).

First of all, the work should be carried out on the translation of modal that should not be free but should have contextual bound and then on its tagging. To translate a modal, the translator should first know the category of the modal (epistemic or non-epistemic) then rephrase the modal (Abdel Fattah, 2005) but the surrounding factors in addition to the tense, aspect, and modality even inside the one category should be studied (Murata et al., 2001) because modality deals with the relationships among the three fundamental elements of a sentence, which are subject, predicator, and complement in order to tag a modal (Moindjie, 2015). 


\section{Global Proceedings Repository \\ American Research Foundation}

ISSN 2476-017X

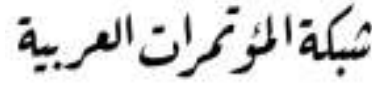

http://arab.kmshare.net/

Available online at http://proceedings.sriweb.org

The Ninth International Scientific Academic Conference

Under the Title "Contemporary trends in social, human, and natural sciences"

$$
\text { المؤتمر العلمي الاكاديمي الدولي التاسع }
$$

تحت عنوان "الاتحاهات المعاصرة في العلوم الاجتماعية، الانسانية، والطبيعية"

17 - 18 يوليو - تموز 2018 - اسطنبول - تركيا

http://kmshare.net/isac2018/

\begin{tabular}{|c|c|c|c|c|c|}
\hline Meanings & English & Arabic & Meanings & English & Arabic* \\
\hline \multirow[t]{4}{*}{ Conclusion } & Must & لا بد & Obligation & Must & يجب/على \\
\hline & & & Necessity & Have to & يتعبن \\
\hline & & & Duty & Should & ينبغي \\
\hline & & & Duty & Ought to & ينبغي \\
\hline Conclusion & May & أمكن & Permission & May & قدر/سمح \\
\hline Conclusion & Can & أمكن & Permission & Can & ستطاع/وسع \\
\hline
\end{tabular}

Table 1 (Abdel Fattah, 2005)

Accordingly, after sorting out the text in terms of mood and aspect, the modal should be tagged as follow: category/ subcategory/ meaning/ element that precedes/ element that follows/ tense/ exceptions, if any, of the sentence.

\section{Arabic and Modality}

Arabic has peculiarities and the main particularity of Arabic when translating modals from or into Arabic is that Arabic doesn't contain a defined modal system but it is mostly lexical; therefore, any word which expresses a modal 


\section{Global Proceedings Repository \\ American Research Foundation}

ISSN 2476-017X

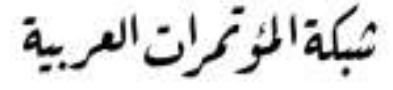

http://arab.kmshare.net/

Available online at http://proceedings.sriweb.org

The Ninth International Scientific Academic Conference

Under the Title "Contemporary trends in social, human, and natural sciences"

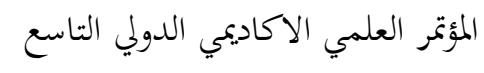

تحت عنوان "الاتحاهات المعاصرة في العلوم الاجتماعية، الانسانية، والطبيعية"

$$
17 \text { - } 18 \text { يوليو - تموز } 2018 \text { - اسطنبول - تركيا }
$$

http://kmshare.net/isac2018/

meaning can be part of the system regardless of its grammatical category. On the other hand, there are other problems like contextuality, ambiguity, and indeterminacy that are associated with the possibility of mistranslations (Abdel Fattah, 2005). Moreover, the absence of Arabic linguistic corpora will lead to failing in reaching a monolithic system of modality (Abdel Fattah, 2005).

Some modals have perfect alternative in Arabic like "must" but others should be contextualized and uses many expressions deontically such as verbs like: تعين، انبغى، احتمل، تحتم، وج، لزم، جاز، قدر، وسع، سمح derived verb stems like من الو اجب، من المفروض، من المكن، من اللازم، من المتعين، من الجائز and modal phrases ;لى ; أفترض، استطاع، أمكن، تمكن (Abdel Fattah, 2005); and there is a tendency to use imperatives when it is a question of deontic meaning which is inherently weak in Arabic, and it seems that most Arabic modals tend to be dynamic or epistemic (Abdel Fattah, 2005). However, ambiguous modals should be reduced if the background of utterances is known through contextualization and rephrasing (Abdel Fattah, 2005). The hereunder table reflects samples taken from the UNDP documents and shows the epistemic tagging of modals to get correct translations.

\begin{tabular}{|c|c|c|c|c|}
\hline Modal & English & Arabic & Tagging for Rules & Translation of \\
& & & & Modal \\
\hline
\end{tabular}




\section{Global Proceedings Repository \\ American Research Foundation}

ISSN 2476-017X

Available online at http://proceedings.sriweb.org

The Ninth International Scientific Academic Conference

Under the Title "Contemporary trends in social, human, and

http://kmshare.net/isac2018/

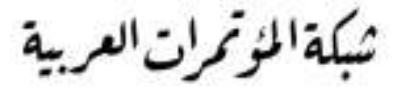

http://arab.kmshare.net/

htp://kmshare.net/isac2018/

\begin{tabular}{|c|c|c|c|c|}
\hline Should & While It should be centered & فيما من المفترض أن & $\begin{array}{l}\text { Impersonal pronoun } \\
\text { "it"+ deontic modal of } \\
\text { duty "should"+ base } \\
\text { form of the verb to be } \\
\text { "be"+ past participle } \\
\text { of a verb that doesn't } \\
\text { mean mentioning }\end{array}$ & من المفترض أن \\
\hline & $\begin{array}{l}\text { Finally, it should be noted that } \\
\text { in both years } 2014 \text { and } 2015 \text {, } \\
\text { Lebanon accounted over } 1 \\
\text { million registered displaced } \\
\text { persons, which constituted } \\
\text { around } 25 \text { per cent of the } \\
\text { Lebanese population and } \\
\text { represented the world's }\end{array}$ & 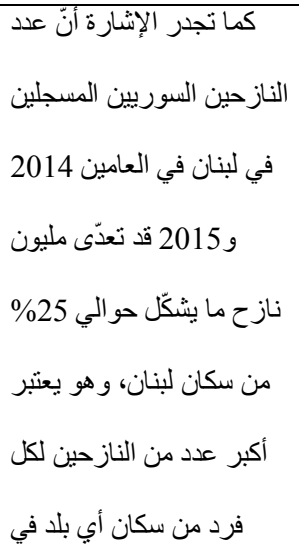 & $\begin{array}{l}\text { Impersonal pronoun } \\
\text { "it"+ deontic modal of } \\
\text { duty "should"+ base } \\
\text { form of the verb to be } \\
\text { "be" + + past participle } \\
\text { of a verb that means } \\
\text { mentioning }\end{array}$ & تجدر الإشارة \\
\hline
\end{tabular}




\section{Global Proceedings Repository \\ American Research Foundation}

ISSN 2476-017X
شبكة المؤرتمرات العربية

http://arab.kmshare.net/

Available online at http://proceedings.sriweb.org

The Ninth International Scientific Academic Conference

Under the Title "Contemporary trends in social, human, and natural sciences"

$$
\text { المؤتمر العلمي الاكاديمي الدولي التاسع }
$$

تحت عنوان "الاتحاهات المعاصرة في العلوم الاجتماعية، الانسانية، والطبيعية"

17 - 18 يوليو - تموز 2018 - اسطنبول - تركيا

http://kmshare.net/isac2018/

\begin{tabular}{|c|c|c|c|}
\hline $\begin{array}{l}\text { highest number of refugees } \\
\text { per inhabitant. }\end{array}$ & 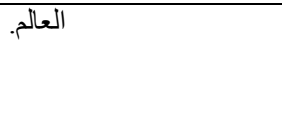 & & \\
\hline $\begin{array}{l}\text { We should look at Syrian } \\
\text { refugees from a humanitarian } \\
\text { perspective. }\end{array}$ & $\begin{array}{l}\text { علينا أن ننظر إلى اللاجئين } \\
\text { السوريين من منظور }\end{array}$ & $\begin{array}{l}\text { Plural pronoun that } \\
\text { reflects the speaker+ } \\
\text { modal of duty } \\
\text { "should"+ base form } \\
\text { of a verb of action }\end{array}$ & علينا \\
\hline $\begin{array}{l}\text { I understood that I should } \\
\text { have a different perspective } \\
\text { on this issue and should not } \\
\text { blame anyone nor throw any } \\
\text { prejudice. }\end{array}$ & فهمت أنه عليّ تغيير وجهة & $\begin{array}{l}\text { Singular pronoun that } \\
\text { reflects the speaker+ } \\
\text { modal of duty } \\
\text { "should" + base form } \\
\text { of a verb }\end{array}$ & عليّ \\
\hline We should all fight against & علينا جميعا محاربة العنف & Plural pronoun that & 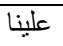 \\
\hline
\end{tabular}




\section{Global Proceedings Repository \\ American Research Foundation}

ISSN 2476-017X

Available online at http://proceedings.sriweb.org

The Ninth International Scientific Academic Conference

Under the Title "Contemporary trends in social, human, and natural sciences"

$$
\text { المؤتمر العلمي الاكاديمي الدولي التاسع }
$$

تحت عنوان "الاتحاهات المعاصرة في العلوم الاجتماعية، الانسانية، والطبيعية"

$$
17 \text { - } 18 \text { يوليو - تموز } 2018 \text { - اسطنبول - تركيا }
$$

http://kmshare.net/isac2018/

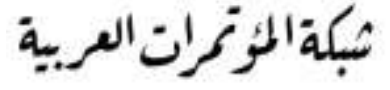

\begin{tabular}{|c|c|c|c|c|}
\hline & violence especially in schools. & وبخاصة في المدارس. & $\begin{array}{l}\text { reflects the speaker+ } \\
\text { modal of duty } \\
\text { "should"+ plural } \\
\text { pronoun "all"+ base } \\
\text { form of a verb of } \\
\text { action }\end{array}$ & \\
\hline \multirow[t]{2}{*}{ Can be } & $\begin{array}{l}\text { Changes and stabilized } \\
\text { conditions in } 2015 \text { compared } \\
\text { to the situation in } 2014 \text { can be } \\
\text { summarized as follows. }\end{array}$ & 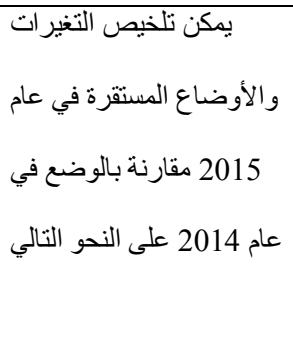 & \multirow[t]{2}{*}{$\begin{array}{l}\text { Permissive deontic } \\
\text { modal "Can"+ base } \\
\text { form of the verb to be } \\
\text { "be"+ past participle } \\
\text { of a verb }\end{array}$} & 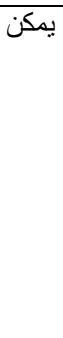 \\
\hline & $\begin{array}{l}\text { As indicated in the EASC of } \\
2014 \text {, the potential } \\
\text { environmental stressors of } \\
\text { ITSs on agricultural areas and }\end{array}$ & 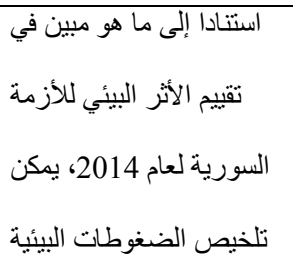 & & \\
\hline
\end{tabular}

http://arab.kmshare.net/ 


\section{Global Proceedings Repository \\ American Research Foundation}

ISSN 2476-017X
شبكة المؤرتمرات العربية

http://arab.kmshare.net/

Available online at http://proceedings.sriweb.org

The Ninth International Scientific Academic Conference

Under the Title "Contemporary trends in social, human, and natural sciences"

$$
\text { المؤتمر العلمي الاكاديمي الدولي التاسع }
$$

تحت عنوان "الاتحاهات المعاصرة في العلوم الاجتماعية، الانسانية، والطبيعية"

$$
17 \text { - } 18 \text { يوليو - تموز } 2018 \text { - اسطنبول - تركيا }
$$

http://kmshare.net/isac2018/

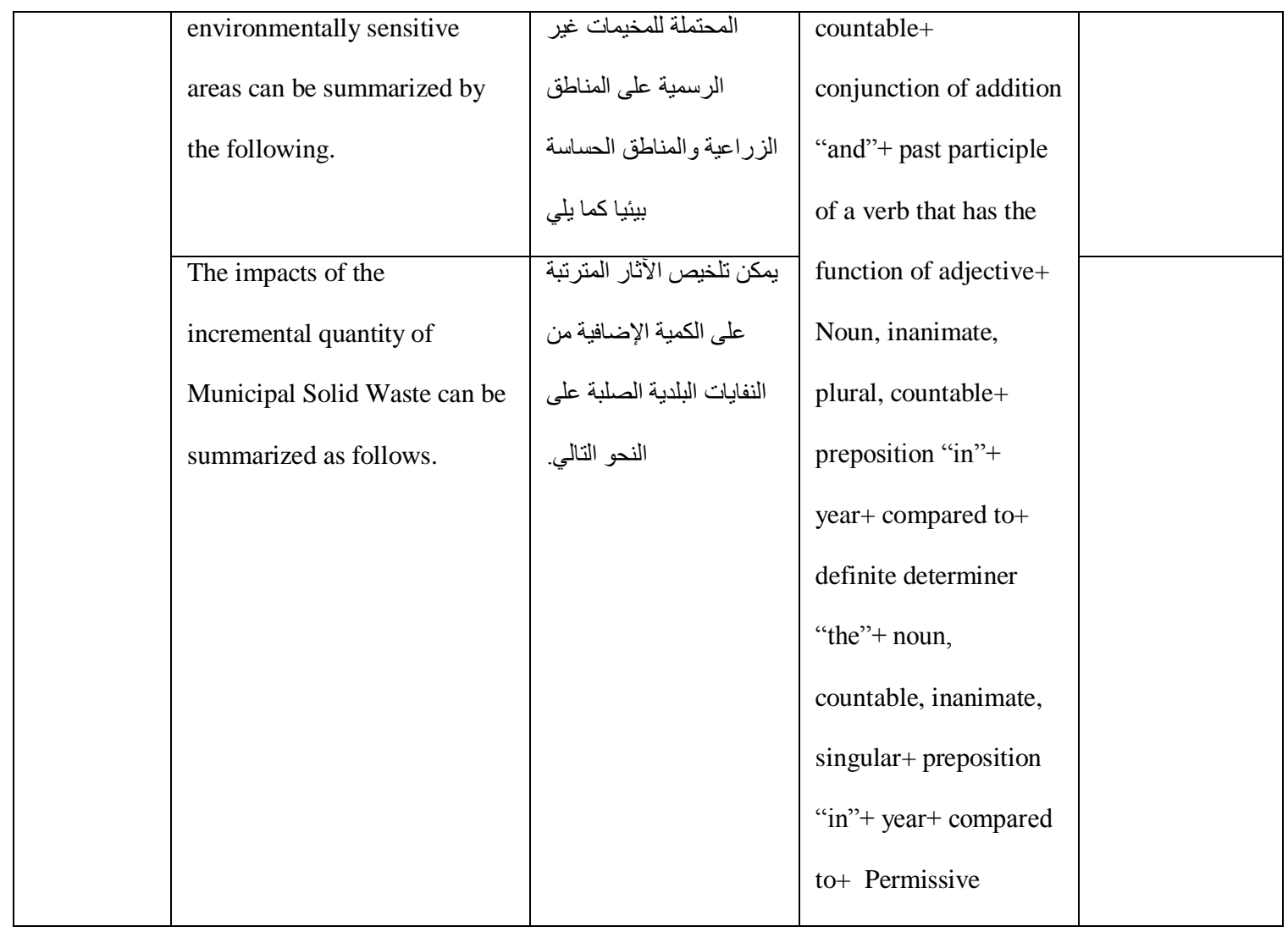




\section{Global Proceedings Repository \\ American Research Foundation}

ISSN 2476-017X
شبكة المؤرتمرات العربية

http://arab.kmshare.net/

Available online at http://proceedings.sriweb.org

The Ninth International Scientific Academic Conference

Under the Title "Contemporary trends in social, human, and natural sciences"

$$
\text { المؤتمر العلمي الاكاديمي الدولي التاسع }
$$

تحت عنوان "الاتحاهات المعاصرة في العلوم الاجتماعية، الانسانية، والطبيعية"

$$
17 \text { - } 18 \text { يوليو - تموز } 2018 \text { - اسطنبول - تركيا }
$$

\begin{tabular}{|c|c|c|c|c|}
\hline & & & $\begin{array}{l}\text { deontic modal "Can"+ } \\
\text { base form of the verb } \\
\text { to be "be"+ past } \\
\text { participle of a verb... }\end{array}$ & \\
\hline Can & $\begin{array}{l}\text { Only the people can } \\
\text { guarantee the sustainability } \\
\text { of social stability. }\end{array}$ & الشعب وحده يضمن استدامة & $\begin{array}{l}\text { Adverb "Only"+ } \\
\text { definite determiner } \\
\text { "the"+ noun, } \\
\text { countable, animate, } \\
\text { plural+ Permissive } \\
\text { deontic modal "Can"+ } \\
\text { guarantee + definite } \\
\text { determiner "the"+ } \\
\text { noun, inanimate, } \\
\text { uncountable, singular+ } \\
\text { of+ adjective+ noun, }\end{array}$ & $\begin{array}{l}\text { The modal is } \\
\text { omitted and is } \\
\text { replaced by the } \\
\text { meaning of the } \\
\text { verb } \\
\text { "guarantee" }\end{array}$ \\
\hline
\end{tabular}

http://kmshare.net/isac2018/ 


\section{Global Proceedings Repository \\ American Research Foundation}

ISSN 2476-017X
شبكة المؤرتمرات العربية

http://arab.kmshare.net/

Available online at http://proceedings.sriweb.org

The Ninth International Scientific Academic Conference

Under the Title "Contemporary trends in social, human, and natural sciences"

$$
\text { المؤتمر العلمي الاكاديمي الدولي التاسع }
$$

تحت عنوان "الاتحاهات المعاصرة في العلوم الاجتماعية، الانسانية، والطبيعية"

$$
17 \text { - } 18 \text { يوليو - تموز } 2018 \text { - اسطنبول - تركيا }
$$

\begin{tabular}{|c|c|c|}
\hline & & $\begin{array}{l}\text { uncountable, } \\
\text { inanimate, singular }\end{array}$ \\
\hline $\begin{array}{l}\text { Yet, Tripoli was one of the } \\
\text { few regions where violent } \\
\text { conflicts persisted, more or } \\
\text { less intensely, until 2014; in } \\
\text { particular in two adjacent } \\
\text { areas, Bab el-Tabbaneh and } \\
\text { Jabal Mohsen, where the } \\
\text { conflict can still erupt again } \\
\text { any time. }\end{array}$ & 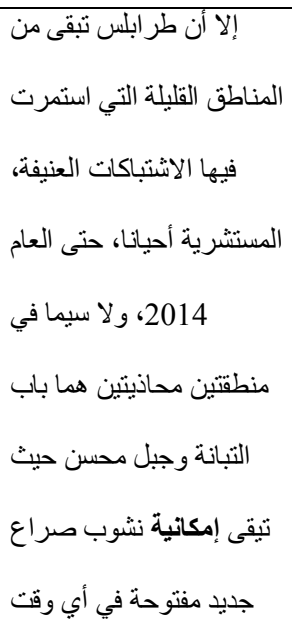 & 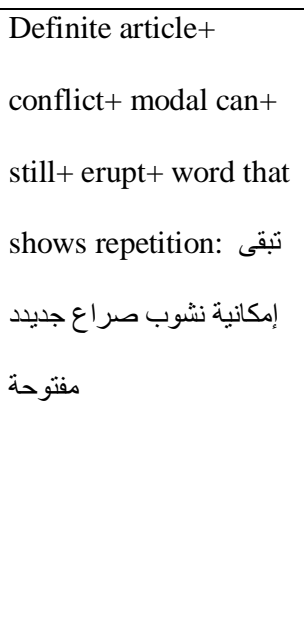 \\
\hline $\begin{array}{l}\text { If media can fuel conflicts, } \\
\text { media can also build peace. }\end{array}$ & 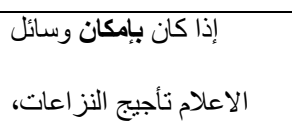 & $\begin{array}{l}\text { Uncountable noun, } \\
\text { inanimate, concept+ }\end{array}$ \\
\hline
\end{tabular}

http://kmshare.net/isac2018/ 


\section{Global Proceedings Repository \\ American Research Foundation}

ISSN 2476-017X

Available online at http://proceedings.sriweb.org

The Ninth International Scientific Academic Conference

Under the Title "Contemporary trends in social, human, and natural sciences"

$$
\text { المؤتمر العلمي الاكاديمي الدولي التاسع }
$$

تحت عنوان "الاتحاهات المعاصرة في العلوم الاجتماعية، الانسانية، والطبيعية"

$$
17 \text { - } 18 \text { يوليو - تموز } 2018 \text { - اسطنبول - تركيا }
$$

http://kmshare.net/isac2018/

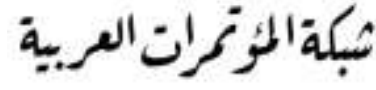

http://arab.kmshare.net/

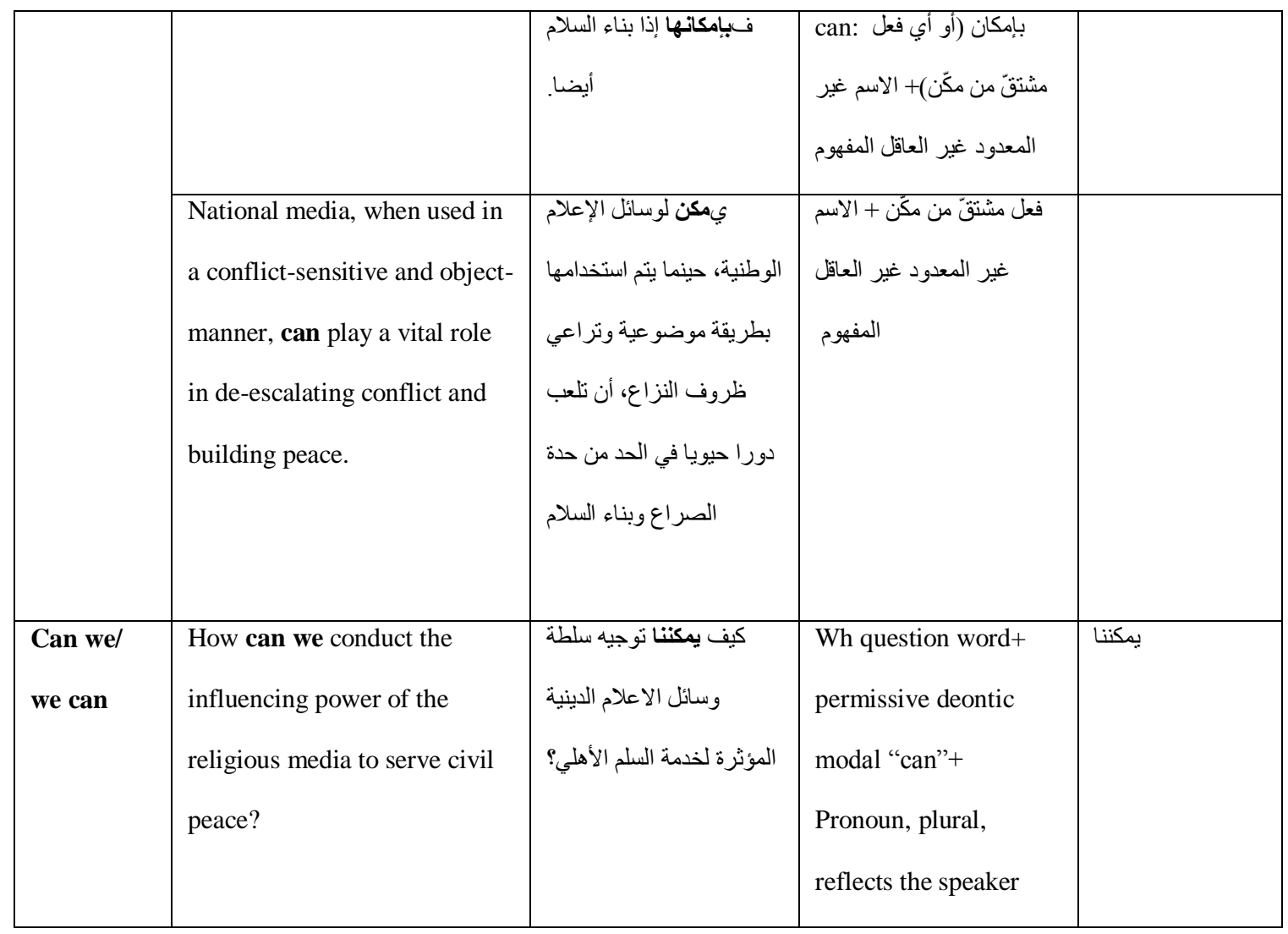




\section{Global Proceedings Repository \\ American Research Foundation}

ISSN 2476-017X
شبكة المؤرتمرات العربية

http://arab.kmshare.net/

Available online at http://proceedings.sriweb.org

The Ninth International Scientific Academic Conference

Under the Title "Contemporary trends in social, human, and natural sciences"

$$
\text { المؤتمر العلمي الاكاديمي الدولي التاسع }
$$

تحت عنوان "الاتحاهات المعاصرة في العلوم الاجتماعية، الانسانية، والطبيعية"

$$
17 \text { - } 18 \text { يوليو - تموز } 2018 \text { - اسطنبول - تركيا }
$$

\begin{tabular}{|c|c|c|c|c|}
\hline & & & $\begin{array}{l}\text { "we" + base form of a } \\
\text { verb of action }\end{array}$ & \\
\hline & $\begin{array}{l}\text { To what extent can we use } \\
\text { religious media content to } \\
\text { ease the situation of Syrian } \\
\text { refugees in Lebanon? }\end{array}$ & 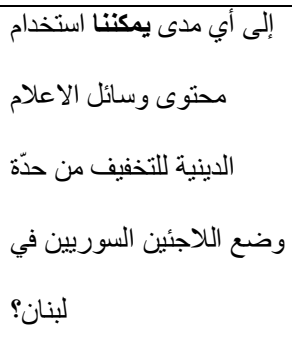 & & \\
\hline & $\begin{array}{l}\text { We can now keep with } \\
\text { techniques, theories and } \\
\text { technology of today. }\end{array}$ & و يمكنتا الآن مو اكبة التقنيات & $\begin{array}{l}\text { Pronoun, plural, } \\
\text { reflects the speaker } \\
\text { "we"+ permissive } \\
\text { deontic modal "can" }\end{array}$ & يمكنتا \\
\hline May & $\begin{array}{l}\text { While some may suffer from } \\
\text { lack of basic services. }\end{array}$ & نقصا في الخدمات الأساسية. & $\begin{array}{l}\text { Conjunction "while"+ } \\
\text { pronoun that reflects } \\
\text { an amount "some"+ }\end{array}$ & قد \\
\hline
\end{tabular}

http://kmshare.net/isac2018/ 


\section{Global Proceedings Repository \\ American Research Foundation}

ISSN 2476-017X

Available online at http://proceedings.sriweb.org

The Ninth International Scientific Academic Conference

Under the Title "Contemporary trends in social, human, and natural sciences"

$$
\text { المؤتمر العلمي الاكاديمي الدولي التاسع }
$$

تحت عنوان "الاتحاهات المعاصرة في العلوم الاجتماعية، الانسانية، والطبيعية"

$$
17 \text { - } 18 \text { يوليو - تموز } 2018 \text { - اسطنبول - تركيا }
$$

http://kmshare.net/isac2018/

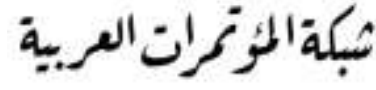

\begin{tabular}{|c|c|c|c|c|}
\hline & & & $\begin{array}{l}\text { deontic modal of } \\
\text { permission "May"+ } \\
\text { base form of a verb }\end{array}$ & \\
\hline Must & $\begin{array}{l}\text { Diversity enriches our } \\
\text { communities; we must use it } \\
\text { as an asset for our } \\
\text { development }\end{array}$ & 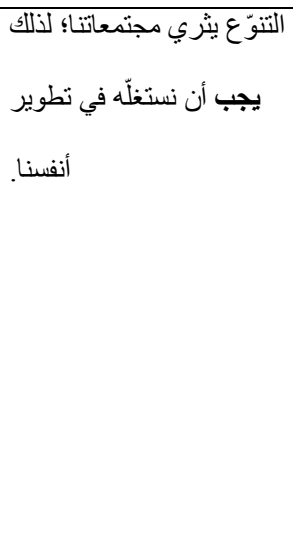 & $\begin{array}{l}\text { Pronoun, plural, } \\
\text { reflects the speaker+ } \\
\text { deontic obligative } \\
\text { modal "must"+ verb of } \\
\text { action/ base form+ } \\
\text { impersonal pronoun, } \\
\text { singular, reflects an } \\
\text { object }\end{array}$ & يجب \\
\hline $\begin{array}{l}\text { Might } \\
\text { have }\end{array}$ & $\begin{array}{l}\text { All the barriers of sharing } \\
\text { intimate and personal stories } \\
\text { that might have a traumatic } \\
\text { background have been }\end{array}$ & تقف تكسير كافة الحواجز التي & $\begin{array}{l}\text { Plural pronoun "all"+ } \\
\text { definite determiner } \\
\text { "the"+ noun, } \\
\text { inanimate, plural, }\end{array}$ & $\begin{array}{l}\text { قد تكون/قد يكون } \\
\text { (based on the } \\
\text { tagging of } \\
\text { Arabic) because }\end{array}$ \\
\hline
\end{tabular}

http://arab.kmshare.net/ 


\section{Global Proceedings Repository \\ American Research Foundation}

ISSN 2476-017X

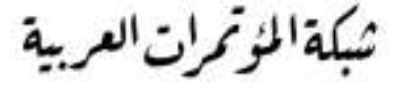

http://arab.kmshare.net/

Available online at http://proceedings.sriweb.org

The Ninth International Scientific Academic Conference

Under the Title "Contemporary trends in social, human, and natural sciences"

$$
\text { المؤتمر العلمي الاكاديمي الدولي التاسع }
$$

تحت عنوان "الاتحاهات المعاصرة في العلوم الاجتماعية، الانسانية، والطبيعية"

$$
17 \text { - } 18 \text { يوليو - تموز } 2018 \text { - اسطنبول - تركيا }
$$

http://kmshare.net/isac2018/

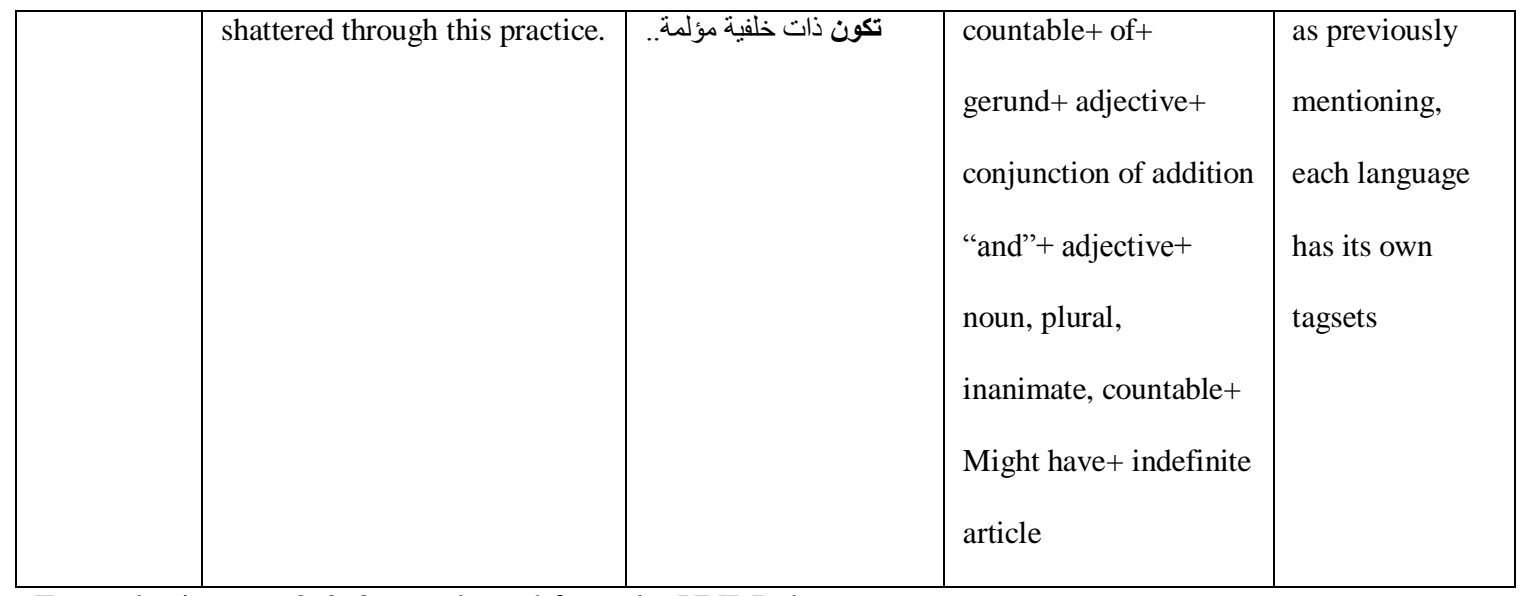

Examples in rows $2 \& 3$ are adopted from the UNDP documents.

\section{Results}

The adoption of the epistemic tagging of modals based on linguistics leads to the following outcomes:

- If there are an impersonal pronoun "it", deontic modal of duty "should", base form of the verb to be "be", and past participle of a verb that doesn't mean mentioning, the translation of the modal is من المفترض أن

- If there are an impersonal pronoun "it", deontic modal of duty "should", base form of the verb to be "be", and past participle of a verb that means mentioning, the translation of should becomes تجدر الإثارة 


\section{Global Proceedings Repository \\ American Research Foundation}

ISSN 2476-017X

Available online at http://proceedings.sriweb.org

The Ninth International Scientific Academic Conference

Under the Title "Contemporary trends in social, human, and natural sciences"

$$
\text { المؤتمر العلمي الاكاديمي الدولي التاسع }
$$

تحت عنوان "الاتحاهات المعاصرة في العلوم الاجتماعية، الانسانية، والطبيعية"

$$
17 \text { - } 18 \text { يوليو - تموز } 2018 \text { - اسطنبول - تركيا }
$$

http://kmshare.net/isac2018/

- If there are Plural pronoun that reflects the speaker, modal of duty "should", and base form of a verb of علينا action, the translation becomes

- If there are permissive deontic modal "Can", base form of the verb to be "be", and past participle of a verb, the translation becomes يمكن

- If there are the adverb "Only"; definite determiner "the"; noun, countable, animate, plural; Permissive deontic modal "Can"; guarantee; definite determiner "the"; noun, inanimate, uncountable, singular; of; adjective; uncountable, inanimate, singular, noun, the modal is omitted and is replaced by the meaning of the verb "guarantee" يضمن

- If there are wh-question word; permissive deontic modal "can"; Pronoun, plural, reflects the speaker "we"; base form of a verb of action, the translation becomes يمكنبا

- If there are the pronoun, plural, reflects the speaker "we"; permissive deontic modal "can", the translation becomes يمكننا

- If there are the conjunction "while"; pronoun that reflects an amount "some"; deontic modal of permission "May"; base form of a verb, the translation becomes قد 


\section{Global Proceedings Repository \\ American Research Foundation}

ISSN 2476-017X

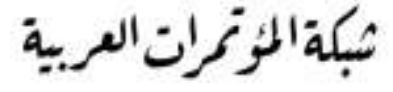

http://arab.kmshare.net/

Available online at http://proceedings.sriweb.org

The Ninth International Scientific Academic Conference

Under the Title "Contemporary trends in social, human, and natural sciences"

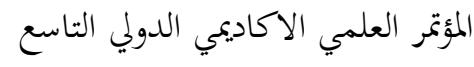

تحت عنوان "الاتحاهات المعاصرة في العلوم الاجتماعية، الانسانية، والطبيعية"

17 - 18 يوليو - تموز 2018 - اسطنبول - تركيا

http://kmshare.net/isac2018/

- If there are the pronoun, plural, reflects the speaker; deontic obligative modal "must"; verb of action/ base form; impersonal pronoun, singular, reflects an object, the translation becomes يجب

- If there are the plural pronoun "all"; definite determiner "the"; noun, inanimate, plural, countable; of; gerund; adjective; conjunction of addition "and"; adjective; noun, plural, inanimate, countable; Might have; indefinite article, the translation becomes قد تكون/قد يكون based on the tagging of Arabic because each language has its own tagsets as previously mentioning.

\section{Recommendations}

The researcher agrees with the following to recommendations whenever parts of speech are tagged for machine translation.

1. Based upon the aforementioned, it is recommended to go with Murata et al. (2001) regarding the uncommon tagging system for all languages; each language should have the tagging that suits its peculiarities for example when translating from Japanese to English, the verb phrase is tagged $\mathrm{Vj}$ while it is usually tagged with $\mathrm{V}$ because the words don't maintain the same sequence when being translated from one 


\section{Global Proceedings Repository \\ American Research Foundation}

ISSN 2476-017X

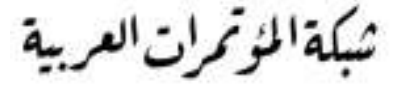

http://arab.kmshare.net/

Available online at http://proceedings.sriweb.org

The Ninth International Scientific Academic Conference

Under the Title "Contemporary trends in social, human, and natural sciences"

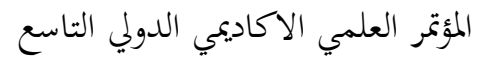

تحت عنوان "الاتحاهات المعاصرة في العلوم الاجتماعية، الانسانية، والطبيعية"

17 - 18 يوليو - تموز 2018 - اسطنبول - تركيا

http://kmshare.net/isac2018/

language to another as shown in the abovementioned examples and as stated by Saussure that language is a set of structured systems that are systematic (Fawcett, 2003) and give structural equivalences (Andriamanankasina, Araki, \& Tochinai, 1999).

2. The tagging process should not be automated and should be carried out by people who have long experience and the intuition and reasoning of translation (Moindjie, 2015).

\section{Conclusion}

Modals can have accurate translation in Machine Translation provided taking into consideration the surrounding parts of speech and doing the tagging process epistemologically departing from the syntactic classification and the translational intuition. Moreover, the tagging process should be manual and different from one language to another. 


\section{Global Proceedings Repository \\ American Research Foundation \\ ISSN 2476-017X}

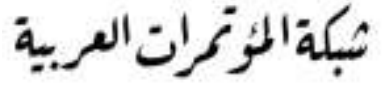

http://arab.kmshare.net/

Available online at http://proceedings.sriweb.org

The Ninth International Scientific Academic Conference

Under the Title "Contemporary trends in social, human, and natural sciences"

$$
\text { المؤتمر العلمي الاكاديمي الدولي التاسع - (لمع }
$$

تحت عنوان "الاتحاهات المعاصرة في العلوم الاجتماعية، الانسانية، والطبيعية"

17 - 18 يوليو - تموز 2018 - اسطنبول - تركيا

http://kmshare.net/isac2018/

\section{References}

(Murata, M., Utiyama, M., Uchimoto, K., Ma, Q., \& Isahara, H. (2001). Correction of Errors in a Modality Corpus Used for Machine Translation by Using Machine-learning Method. Communications Research Laboratory. Japan. Retrieved from https://arxiv.org/pdf/cs/0105001.pdf

Abdel Fattah, M. (2005). On The Translation of Modals From English Into Arabic and Vice Versa: The Case of Deontic Modality. Babel. 51 (2). doi:10.1075/babel.51.1.03abd

Alqudsi, A., Omar, N., \& Shaker, K. (2012). Arabic Machine Translation: A Survey. Artificial Intelligence $\begin{array}{llllll}\text { Review. } & 42 & \text { (4). } & \text { Doi: } & \text { 10.1007/s10462-012-9351-1. } & \text { Retrieved }\end{array}$ https://www.researchgate.net/publication/230817890_Arabic_Machine_Translation_A_survey

Andriamanankasina, T., Araki, K., \& Tochinai, K. (1990). Example-Based Machine Translation of Part-OfSpeech Tagged Sentences by Recursive Division. MT Summit VII. Hokkaido University. Retrieved from http://citeseerx.ist.psu.edu/viewdoc/download?doi=10.1.1.501.3150\&rep=rep1\&type=pdf 


\section{Global Proceedings Repository \\ American Research Foundation \\ ISSN 2476-017X}

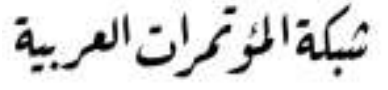

http://arab.kmshare.net/

Available online at http://proceedings.sriweb.org

The Ninth International Scientific Academic Conference

Under the Title "Contemporary trends in social, human, and natural sciences"

$$
\text { المؤتمر العلمي الاكاديمي الدولي التاسع }
$$

تحت عنوان "الاتحاهات المعاصرة في العلوم الاجتماعية، الانسانية، والطبيعية"

17 - 18 يوليو - تموز 2018 - اسطنبول - تركيا

http://kmshare.net/isac2018/

Centre for Local Economic Strategies. Research Methods Handbook Introductory guide to research methods for social research: Introductory guide to research methods for social research. Manchester M4 5DL. Stuart MacDonald \& Nicola Headlam.

Dellschaft, K., \& Staab, S., (2008). An Epistemic Dynamic Model for Tagging Systems. $19^{\text {th }}$ Conference on Hypertext and Hypermedia HT'08. doi: acm.org/10.1145/1379092.1379109. Retrieved from http://citeseerx.ist.psu.edu/viewdoc/download?doi=10.1.1.175.1802\&rep=rep1\&type=pdf

Farghali, A. (2010). Arabic Machine Translation: A Developmental Perspective. International Journal on Information and Communication Technologies. 3 (3). Retrieved from http://www.ieee.ma/IJICT/IJICT-SIBouzoubaa-3.3/2\%20-\%20paper_farghaly.pdf

Fawcett, P., (2003). Translation and Language: Linguistic Theories Explained. Manchester, UK \& Northampton, MA: ST JEROME Publishing

Hutchins, J. (2001). Machine Translation and Human Translation: In Completion or in Complementation. International Journal of Translation. 13 (1-2). Retrieved from http://mt-archive.info/IJT-2001-Hutchins.pdf 


\section{Global Proceedings Repository \\ American Research Foundation \\ ISSN 2476-017X}

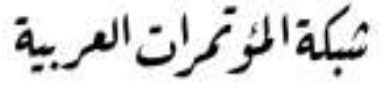

http://arab.kmshare.net/

Available online at http://proceedings.sriweb.org

The Ninth International Scientific Academic Conference

Under the Title "Contemporary trends in social, human, and natural sciences"

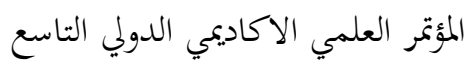

تحت عنوان "الاتحاهات المعاصرة في العلوم الاجتماعية، الانسانية، والطبيعية"

17 - 18 يوليو - تموز 2018 - اسطنبول - تركيا

http://kmshare.net/isac2018/

Khalilov, M. (2009). New Statistical and Syntactic Models for Machne Translation (Doctoral dissertation). Retrieved from http://www.easybib.com/guides/citation-guides/apa-format/how-to-cite-a-thesis-dissertation-apa/

Melby, A., \& Warner, T. (1995). The Possibility of Language: A Discussion of the Nature of Language, With Implications for Human and Machine Translation. Amsterdam: John Benjamins Publishing.

Moindjie, M. (2015). The Function of Modality in Translation. International Journal of Comparative Literature \& Translation Studies. 3(2). doi: 10.7575/aiac.ijclts.v.3n.2p.11

Palmer, F.R. 2001. Mood and Modality, $2^{\text {nd }}$ Edition. Cambridge: C.U.P. xxi+236 pp.

Technische Universitat Dresden (2017). Machine Translation: Between Past and Future. The Art of Translation

Trujillo, A. (1999). Translation Engines: Techniques for Machine Translation. Verlag, Berlin: Springer. doi: 10.1007/978-1-4471-0587-9

United Nations Development Programme. Religious media to serve civil peace: reflection and action. Retrieved from http://www.lb.undp.org/content/lebanon/en/home/ourwork/crisispreventionandrecovery/successstories/ReligiousMedia-to-Serve-Civil-Peace-Reflection-and-Action.html 


\section{Global Proceedings Repository \\ American Research Foundation}

ISSN 2476-017X

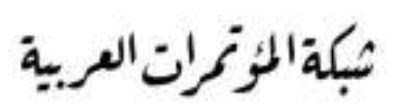

http://arab.kmshare.net/

Available online at http://proceedings.sriweb.org

The Ninth International Scientific Academic Conference

Under the Title "Contemporary trends in social, human, and natural sciences"

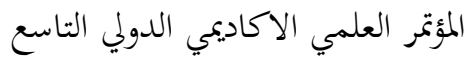

تحت عنوان "الاتحاهات المعاصرة في العلوم الاجتماعية، الانسانية، والطبيعية"

17 - 18 يوليو - تموز 2018 - اسطنبول - تركيا

http://kmshare.net/isac2018/

United Nations Development Programme. (2017). Stimulating the commitment of national news agency reporters to strengthen civil peace. Retrieved from

http://www.lb.undp.org/content/lebanon/en/home/presscenter/articles/2017/08/28/stimulating-the-commitment-ofnational-news-agency-reporters-to-strengthen-civil-peace.html

Zughoul, M.R., \& Abu-Alshaar, A.M. (2005). English/ Arabic/ English Machine Translation: A Historical Perspective. Meta. 50 (3). doi: 10.7202/011612ar. Retrieved from https://www.erudit.org/en/journals/meta/2005v50-n3-meta979/011612ar/ 